\title{
Türkçeyi Yabancı Dil Olarak Öğreten Öğretmenleri Değerlendirme Ölçeği
}

\begin{tabular}{lccc}
\hline MAKALE TÜRÜ & Başvuru Tarihi & Kabul Tarihi & Erken Görünüm Tarihi \\
Araştırma Makalesi & 26.01 .2018 & 19.07 .018 & 19.07 .2018 \\
\hline
\end{tabular}

Filiz Mete iD ${ }^{1}$

Hacettepe Üniversitesi

Öz

Bu araştırmada amaç; "Yabancı Dil Olarak Türkçe (YDOT) Öğretmeni Değerlendirme Ölçeğii" geliştirmektir. Bu ölçekle öğretmenlerin etkililik düzeyi belirlenecektir. Böylece öğretmenlerin geliştirilmesi ve iyileştirilmesi gereken eksik yönlerini ortaya çıkaran bir ölçek elde edilecektir. $\mathrm{Bu}$ amaç doğrultusunda öncelikle, öğretmen niteliklerini ifade eden maddeler belirlenmiştir. Elde edilen maddelere faktör analizi yapılmıştır. Toplanan çok sayıdaki madde anlamlı, az sayıda ve birbirinden bağımsız faktörler altında toplanmıştır. Araştırmaya Türkçeyi yabancı dil olarak öğreten 98 öğretmen katılmıştır. Veri toplama aracı olarak beşli likert tipinde 46 maddelik bir ölçek formu tasarlanmış ve uygulanmıştır. Yapı geçerliğinin ve güvenirliğinin istatistiksel olarak belirlenmesinde; madde analizi, faktör analizi ve cronbach's alfa güvenirlik katsayısı hesaplamaları yapılmıştır. Analizler sonucu dokuz boyut 30 maddelik bir ölçek elde edilmiş, boyutlar ilișkilendirilerek üç (bilişsel, duyuşsal, davranıșsal) grupta toplanmıștır. Çalışmada kullanılan ölçeğin güvenirlik düzeyinin belirlenmesi için yapılan chronbach's alfa katsayis1 0.723 olarak elde edilmiştir.

Anahtar sözcükler: Yabancı dil olarak Türkçe öğretimi, öğretmen değerlendirme, faktör analizi

\footnotetext{
${ }^{1}$ Doç. Dr., Eğitim Fakültesi, Türkçe ve Sosyal Bilimler Eğitimi Bölümü, Türkçe Eğitimi Anabilim Dalı, filizmete@ hacettepe.edu.tr, https://orcid.org/0000-0002-8835-3884
} 
Kökeni yıllar öncesine dayanan Türkçe, dünyanın en zengin ve en eski dillerinden birisidir. Ancak, zengin tarihî geçmişi, gramer yapısının sağlamlığı ya da çok kişi tarafından kullanılıyor olması, o dilin dünya dilleri arasında ilk sıralarda bulunmasını sağlamaz. Yabancı bir kültürün dilini öğrenmek, o kültürü öğrenmeyi gerektirmektedir. "Yabancı dil öğretiminin tarihiyle ilgili yapılan araştırmalarla M.Ö. $2225^{\prime}$ te Akadların Sümer ülkesini ele geçirdikten sonra kendilerinden daha üstün bir uygarlığa sahip olan Sümerlerin dilini öğrendiği ve böylece insanlık tarihinde ilk kez yazılı ve sözlü yabancı dil öğretiminin başlamış olduğu tespit edilmiştir” (Hengirmen, 1997, s. 3).

Türkiye, yabancı dil olarak Türkçe öğretimi konusunda oldukça geç kalmıştır. Türk dili ve edebiyatı ve Türkçe eğitimi programları Türkçenin öğretilmesini kapsayan bölümlerdir. Yabancı bir dilin nasıl öğretilmesi gerektiği ise bu bölümlerin dışında, yabancı dillerin öğretimi bölümlerinin kapsama alanındadır. Oysa Türkçenin yabancı dil olarak öğretilmesi konusu, söz konusu alanların kesişme noktasında olan ama tamamen farklı bir alandır. Dolayısıyla farklı bir öğretmen yetiştirme programı ve öğretmen nitelikleri gerektirmektedir.

Yabancı dil olarak Türkçe alanı; dört dil becerisinin öğretimini kapsamaktadır. Bu yönüyle Türkçe öğretmenliği programının alanına girer. Ancak kültür aktarımı için gerekli olan edebi metin bilgisi ile Türk dili ve edebiyatı programlarının ve yabancı dil öğretimi ilke, yöntem, tekniklerinin kullanılmasını gerektirdiği için yabancı dil öğretmenliği programlarının kesişme alanıdır. Yabancı dil olarak Türkçe öğretimi alanına ilişkin gösterim Şekil 1'de sunulmuştur.

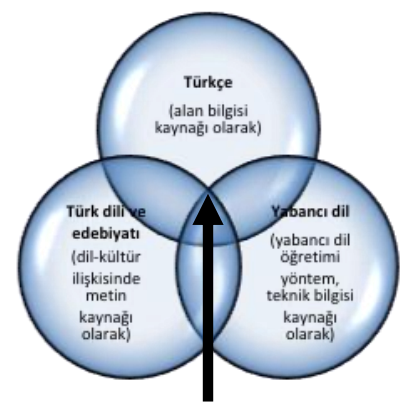

Şekil 1. Yabancı dil olarak Türkçe öğretimi alanı (Mete, 2012)

Türkçenin yabancı dil olarak öğretilmesi konusunda hazırlanan özel bir yetiştirme programının olmayışı sorun kaynağı olarak görülmektedir. Son dönemlerde bazı üniversite ve kurumlarda ücret karşılığı Yabancılara Türkçe Öğretimi sertifika programları bulunmaktadır. Ancak bu sertifika programlarındaki ücret, içerik ve öğretim elemanlarındaki farklılıklar, farklı programlar kapsamında yetiştirilen öğretmenlerin niteliğinde de farklılıklara neden olmakta ve uygulamalara yansımaktadır. $\mathrm{Bu}$ da sorunun çözümünden uzak daha fazla sorunlara neden 
olmaktadır. Oysa Türkçenin yabancı bir dil olarak öğretimi sosyokültürel olduğu kadar ekonomik katkı da sağlayabilecek bir konudur.

"Türkçenin yabancı dil olarak öğretimi alanında görev yapacak uzmanları yetiştirecek lisans programlarının eksikliği, bu programların hangi fakültelerde, hangi bölümlerin altında açılması gerektiği tartışmaları son 20 yıla damgasını vurmuştur" (Yıldız ve Tunçel, 2012, s. 564).

Eğitim öğretim alanında en temel ve etkili bileşen öğretmendir. Bu bağlamda Türkçeyi yabancı dil olarak öğretecek eğitim elemanlarının alanla ilgili özel bir eğitim almış olması, alana ilişkin bilgilerinin yeterli olması ve Türkçeyi doğru ve etkili kullanabiliyor olması önemlidir. Ancak, öncelikle alanı için gerekli olan, öğretmenden beklenilen niteliklerin tanımlanması gerekmektedir.

Millı̂ Eğitim Bakanlığı (MEB) 2004 yılında Temel Eğitime Destek Projesi kapsamında ögretmenin sahip olması gereken bilgi, beceri, tutum ve değerleri tanımlayan öğretmen yeterliklerini belirleme çalışmalarına başlamıştır. Belirlenen yeterliklerin performansı vurguladığı ve yeterlikler kapsamında oluşturulan performans göstergelerinin öğretmenlerin performans değerlendirmesinde de kullanılmasının amaçlandığı belirtilmektedir (MEB, 2010). Böylece MEB tarafindan Öğretmenlik Mesleği Genel Yeterlikleri, Türkçe Öğretmeni Özel Alan Yeterlikleri ve Türk Dili ve Edebiyatı Özel Alan Yeterlikleri ile İngilizce Öğretmeni Özel Alan Yeterlikleri belirlenerek gereken performans tanımları yapılmıștır. Performans değerlendirme için ölçüm araçlarının oluşturulması gerekmektedir. Ancak ölçme aracının "performansı ölçebilmesi için öncelikle performansın açık bir şekilde tanımlanması gerekmektedir" (Özer, 2009, s. 11). Ancak yabancı dil olarak Türkçe öğretmenlerinin yeterlik alanları ve performans göstergeleri henüz kurumsal olarak belirlenmemiştir.

$\mathrm{Bu}$ araştırmada öğretmen performanslarının ölçülebilmesine olanak sağlayacak bir ölçek geliştirebilmek adına kullanılan maddeler, Mete'nin 2013 yılında yapmış olduğu "Türkçeyi Yabancı Dil Olarak Öğreten Öğretmenlerin Özel Alan Yeterlikleri Üzerine Bir Araştırma" başlıklı doktora tezi için öğretmenlerle gerçekleştirilen görüşmeler ve anket çalışmaları sonucunda elde ettiği performans göstergelerinden oluşturulmuştur.

$\mathrm{Bu}$ araştırmanın amacı, hem Türkçenin yabancı bir dil olarak öğretilmesi konusunda öğretmen yetiştirilmesi için özel program oluşturulmasına yol gösterecek hem de görev başında Türkçeyi yabancı bir dil olarak öğreten öğretmenlerin iyileştirmesi gereken eksik yönlerini belirlemelerini sağlayacak bir değerlendirme ölçeği geliştirmektir. Ölçekler, ölçme işlemini kolaylaştırmanın yanı sıra, elde edilen sonuçların niteliğinin de belirlenmesini sağlamaktadır (Karakoç ve Dönmez, 2014, s. 40). Bu bağlamda alanın gelişimine yararlı olacağı düşünülmektedir. 


\section{Yöntem}

Araştırmanın kapsamı, "Yabancı Dil Olarak Türkçe (YDOT) Öğretmeni Değerlendirme Ölçeği” geliştirmektir. Bu ölçekle öğretmenlerin etkililik düzeyi belirlenecektir. Böylece hem Türkçenin yabancı bir dil olarak öğretilmesi konusunda öğretmen yetiştirilmesi için özel program oluşturulmasına yol gösterecek hem de görev başında Türkçeyi yabancı bir dil olarak öğreten öğretmenlerin iyileştirmesi gereken eksik yönlerini belirlemelerini sağlayacak bir ölçek elde edilmiştir. Bu amaç doğrultusunda, ölçekte kullanılmak üzere belirlenen maddelere faktör analizi yapılmıştır. Aşağıda, çalışma yöntemi aşamalı olarak açıklanmaktadır.

İşlem

Kuramsal çerçevenin oluşturulması. Kuramsal çerçevenin belirlenmesi iki aşamada sağlanmıştır. İlk aşamada; Türkçenin yabancı bir dil olarak öğretilmesi ile ilgili çalışmalar (Barın, 2004; Durak, 2006; Erdem, 2009; Gedik, 2009; Hengirmen, 1993; İşcan, 2011; Kaya, 1994; Tosun, 2005; Yıldız, 2012; vb.) ikinci aşamada ise öğretmen niteliği ile ilgili (Arslan ve Özpınar, 2008; Büyükkaragöz ve Kesici, 1996; Çelikten, Şanal ve Yeni, 2005; Glatthorn, Jones ve Bullock, 2006; MEB, 2010; Seferoğlu, 2004; Türkoğlu, 1991; vb.) alanyazın taraması yapılarak incelenmiştir.

Ölçek formatının ve madde havuzunun oluşturulması. Alanyazın incelenmesi sonucunda, eğitim araştırmalarında öğretmen niteliklerinin belirlenmesi ve değerlendirilmesine yönelik birçok boyut ortaya çıkmıştır. Bu boyutlar hem öğretmenlik mesleğini hem de alanın niteliklerini kapsar özellikte çeşitlilik içermektedir. $\mathrm{Bu}$ çalışmada konu, Türkçeyi yabancı bir dil olarak öğreten öğretmenlerdir. Bu bağlamda çalışma maddeleri hem genel olarak öğretmenlik mesleği ile ilgili boyutlardan hem de Mete'nin (2013) yabancı dil olarak Türkçe öğretenlerin nitelikleriyle ilgili gerçekleştirdiği araştırma sonucunda belirlenen maddelerden oluşturulmuştur. Ayrıca MEB'in öğretmenden beklenilen alan performanslarını tanımladığı; Türkçe Öğretmenliği, Türk Dili ve Edebiyatı ile İngilizce Öğretmenliği Özel Alan Yeterlikleri maddelerinden de yararlanılmıştır. Maddeler belirlenirken ve faktörler adlandırılırken özellikle bu boyutlar dikkate alınmıştır. Böylece ölçek formu için 46 maddelik bir madde havuzu oluşturulmuştur.

İfadelerin sade ve anlaşılır olmasına, her maddenin sadece bir yargıyı karşılamasına özen gösterilmiştir. Ölçek, beşli Likert toplama sıralama tekniği formatında, öğretmenlerin ifadelere katılma derecelerini işaretleyecekleri, "1) Hiç Katılmıyorum, 2) Katılmıyorum, 3) Kararsızım, 4) Katılıyorum, 5) Tamamen katılıyorum" şeklinde oluşturulmuştur. 
Uzman görüşüne başvurulması. Maddelerin; konuyla doğrudan ilişkili olup olmadığı, yer alması gerekli görülüp görülmediği, açık ve anlaşılır bir şekilde ifade edilip edilmediği sorgulanmak üzere uzman görüşüne başvurulmuştur. Uzman olarak Türkçenin yabancı dil olarak öğretilmesi konusunda çalışmaları bulunan iki akademisyen ile bir ölçme değerlendirme uzmanı belirlenmiş ve görüşleri alınmıştır. Uzman önerileri doğrultusunda birkaç maddede ifade düzeltmesine gidilmiş ve taslak ölçek maddelerine son şekli verilmiştir.

Ön uygulama ve ölçeğin düzenlenmesi. Beş öğretmen ile bir pilot uygulama çalışması yürütülerek ölçeğin öğretmenler tarafından nasıl anlaşıldığı ve nasıl cevaplandığının anlaşılması amaçlanmıştır. Öğretmenlerin bu bakış açısı ile ölçeği doldurmaları istenmiştir. $\mathrm{Bu}$ süreçte ise iki madde öğretmenler tarafından net bulunmadığından anlaşılabilirliği artırmak için düzenleme yapılmış ve bu maddeler sadeleştirilmiştir. Böylece pilot uygulamadan sonra ölçek dil ve anlatım yönünden incelenerek, ayrıca genel olarak yapısıyla ilgili düzenlemeler yapılarak son biçimini almıştır.

Ölçeğin geçerliği ve güvenirliği. Ölçeğin yapı geçerliğinin ve güvenirliğinin istatistiksel olarak belirlenmesi için; madde analizi, faktör analizi ve cronbach'ın alfa güvenirlik katsayısı hesaplamaları yapılmıştır.

\section{Çalışma Grubu}

Faktör analizi için örneklemin genellikle ölçekte bulunan madde sayısının katılımcı sayısından ideal olarak en az beş katı olmasının önerildiği, ilişki katsayılarının küçük örneklemlerden kestirildiyse daha az güvenilir olma eğiliminde olduğu, dolayısıyla örneklem büyüklüğüne karar verilirken ele alınan değişkenler arasındaki ilişkilerin güvenilir bir biçimde yorumlanmasını sağlayacak yeterlikte olmasının önemli olduğu belirtilmektedir. Büyüköztürk (2002, s. 80)'e göre, "Alanyazına göre değişken sayısı çok büyük olmamak ve belirgin faktörler olmak koşuluyla, 100 ile 200 arasındaki örneklem büyüklüğü yeterli olur ayrıca eğer güçlü, güvenilir ilişkiler ve az sayıda belirgin faktör varsa, örneklem büyüklüğünün, değişken sayısından fazla olması koşuluyla 50 olarak bile kararlaştırılabilir.” Bu araştırmanın örneklem sayısının Türkçe öğretmeni olarak ele alındığında yeterli olmayacağı düşünülebilir. Ancak söz konusu öğretmenlerin sadece Türkçeyi yabanc1 bir dil olarak öğreten öğretmenler olduğu göz önüne alındığında örneklem sayısının zaten sınırlı olan tüm evreni temsil etmeye yeterli olduğu söylenebilir. Katılımcıların demografik özellikleri Tablo 1'de verilmiştir.

Tablo 1.

Katılımclların Demografik Özellikleri

\begin{tabular}{lcc}
\hline Cinsiyet & Frekans & \% \\
Erkek & 51 & 52.05 \\
Kadın & 47 & 47.95 \\
Toplam & $\mathbf{9 8}$ & $\mathbf{1 0 0}$ \\
\hline
\end{tabular}


Tablo 1 (devam)

\begin{tabular}{lcc}
\hline Öğrenim durumu & Frekans & \% \\
Lisans & 85 & 86.74 \\
Yüksek lisans & 11 & 11.22 \\
Doktora & 2 & 2.04 \\
Toplam & $\mathbf{9 8}$ & $\mathbf{1 0 0}$ \\
\hline Mezuniyet & & \\
Türk dili ve edebiyatı & 33 & 33.67 \\
Türkçe eğitimi & 29 & 29.60 \\
Yabancı diller & 36 & 36.73 \\
Toplam & $\mathbf{9 8}$ & $\mathbf{1 0 0 . 0 0}$ \\
\hline Görev yerleri & & \\
Yurt içi & 62 & 63.26 \\
Yurt diş1 & 36 & 36.73 \\
Toplam & $\mathbf{9 8}$ & $\mathbf{1 0 0 . 0 0}$ \\
\hline
\end{tabular}

Tablo 1 incelendiğinde katılımcıların 51'inin erkek, 47'sinin kadın olduğu; 85'inin lisans, 11'inin yüksek lisans ve ikisinin doktora mezunu oldukları görülmektedir. Mezun olunan bölümlerde ise 33 Türk dili ve edebiyatı ve 29 Türkçe eğitimi mezunu bulunmaktadır. Yabancı dil bölümlerinden ise 11 İngilizce, dokuz Almanca, sekiz Fransızca ve diğer yabancı dillerden sekiz kişinin mezun olduğu belirtilmektedir. Ayrıca katılımcıların en az bir yıl en fazla 22 yıl arası yabancı dil olarak Türkçe öğretim deneyimine sahip öğretmenlerden oluştuğu belirlenmiştir.

\section{Bulgular}

Çalışmadan elde edilen bulgular, dört ayrı aşamada sunulmuştur.

\section{Aşama: Verilerin Varsayımları Karşılama Durumu}

$\mathrm{Bu}$ çalışma kapsamında elde edilen verilerin faktör analizi için gerekli varsayımları karşılayıp karşılamadığını belirlemek amacıyla Bartlett testi ve KMO (Kaiser-Meyer-Olkin) katsayısı sonuçları değerlendirilmiştir (Büyüköztürk, 2007). $\mathrm{Bu}$ çerçevede, KMO değerinin 0,50'den büyük çıkması ve Bartlett testi sonucunun anlamlı çıkması beklenmektedir. Bu çalışma veri setinin faktör analizi için uygun olup olmadığının belirlenmesi için yapılan KMO ve Bartlett Küresellik testi sonucunda KMO değeri 0.706; Bartlett küresellik testi sonucunun anlamlılık düzeyi $\mathrm{p}<.05$ olduğu için veri setinin faktör analizi için uygun olduğu belirlenmiştir.

\section{Așama: Ölçeğin Geçerlik İncelemesi}

Ölçeğin faktör yapısının belirlenip geçerliğinin tespit edilmesi amacıyla faktör analizi yapılmıştır. Maddelerin faktör altında ağırlıkları incelendiğinde; birçok maddenin faktörle olan ilişkisini açıklayan faktör ağırlık değerinin 0.45 'in altında olduğu ve yapıya uymadığı belirlenmiştir. Böylece söz konusu maddelerin çalışma dışı bırakılması gerektiğine karar verilmiştir. Böylece, toplam 46 maddeden 1-4-5-1013-14-16-21-22-27-32-33-38-41-45 ve 46 numaralı 16 madde çalışma dışı bırakılıp 
analiz tekrar edilmiştir. Yapılan incelemede binişikliğin pek çok maddede dört dil becerisini (dinleme-konuşma-okuma-yazma) ayrı ayrı kapsayan ifadeler olduğu görülmüştür. Bu bağlamda daha önce ayrı ayrı ifadelerle yer alan dil becerilerinin bütünde ifade edilmesinin gerektiği belirlenmiştir. Böylece faktör yük değerleri 0.45 üzeri olan 30 madde taslak ölçek maddeleri olarak analiz sürecine dâhil edilmiştir. Kalan 30 madde için veri setinin faktör analizi için uygunluğu incelendiğinde KMO katsayısının 0.806; Bartlett küresellik testi anlamlılık düzeyinin ise $p<0.05$ olduğu tespit edildiği için veri setinin faktör analizi için uygun olduğu tekrar görülmüştür. Faktör analizinde ise varimax yöntemi kullanılmıştır. 30 madde için yapılan analizler sonucunda, faktör sayısına karar vermede Yamaç Birikinti Grafiği'nden yararlanılmıştır. Şekil 2'de yamaç birikinti grafiği sunulmuştur.

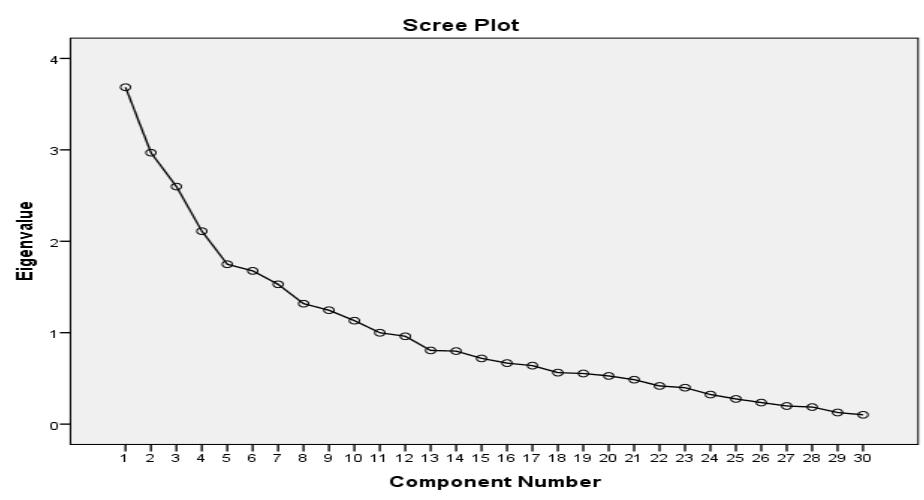

Şekil 2. Yamaç birikinti grafiği

Analizler sonucu, özdeğeri birden büyük olan faktör sayısı dokuz olduğu için, kalan 30 maddenin dokuz faktör altında ağırlıklandığı belirlenmiştir. İlk faktör, toplam varyansın \% 12.28'ini açıklamaktadır. Dokuz faktörün birlikte, toplam varyansın \% 62.94'ünü açıkladığı görülmüştür. Sosyal bilimler alanında gerçekleştirilen araştırmalarda "toplam varyans oranının \% 40 ile \% 60 arasında değer alması" ölçeğin faktör yapısının güçlülüğünü göstermektedir (Scherer, Wiebe, Luther ve Adams, 1988 akt. Tavşancıl, 2002). Bu durumda ölçeğin toplam varyans oranının yeterli bir değere denk geldiği görülmektedir.

Ölçeğin yapı geçerliğini incelemek amacıyla açımlayıcı faktör analizi yapılmıştır. Bu süreçte, ilk aşamada sonuçları yer alan Bartlett Sphericity testi ve Kaiser-Meyer-Olkin (KMO) özdeğer çizgi grafiği, temel bileşenler analiz sonuçları, maddelerin ortak faktör varyans değerleri ve "varimax" döndürme yöntemi uygulanmıştır. Maddelerin hangi faktör altında ağırlıklandığı Tablo 2'de verilen bileşen matrisinde görülmektedir. 
Tablo 2.

Bileşen Matrisi

\begin{tabular}{|c|c|c|c|c|c|c|c|c|c|}
\hline & \multicolumn{9}{|c|}{ Faktörler } \\
\hline & 1 & 2 & 3 & 4 & 5 & 6 & 7 & 8 & 9 \\
\hline M3 & .742 & & & & & & & & \\
\hline M43 & .690 & & & & & & & & \\
\hline M29 & .638 & & & & & & & & \\
\hline M15 & .614 & & & & & & & & \\
\hline M30 & .580 & & & & & & & & \\
\hline M25 & & .758 & & & & & & & \\
\hline M8 & & .692 & & & & & & & \\
\hline M40 & & .561 & & & & & & & \\
\hline M35 & & .546 & & & & & & & \\
\hline M17 & & .450 & & & & & & & \\
\hline M2 & & .459 & & & & & & & \\
\hline M11 & & & .839 & & & & & & \\
\hline M12 & & & .839 & & & & & & \\
\hline M7 & & & & .777 & & & & & \\
\hline M19 & & & & .682 & & & & & \\
\hline M31 & & & & .624 & .538 & & & & \\
\hline M18 & & & & & .846 & & & & \\
\hline M34 & & & & & .693 & & & & \\
\hline M6 & & & & & & .668 & & & \\
\hline M24 & & & & & & .537 & & & \\
\hline M23 & .453 & & & & & .525 & & & \\
\hline M20 & & & & & & .506 & & & \\
\hline M37 & & & & & & & .828 & & \\
\hline M28 & & & & & & & .720 & & \\
\hline M11 & & & & & & & & .836 & \\
\hline M36 & & & & & & & & .812 & \\
\hline M42 & & & & & & & & & .754 \\
\hline M9 & & & & & & & & & .635 \\
\hline M44 & & & & & & & & & .487 \\
\hline M26 & & & & & & & & & .726 \\
\hline
\end{tabular}

Bir değişkenin sadece bir faktör ile ilişkili olması beklenir (Büyüköztürk, 2002, s. 478). Ancak Tablo 2'de görüldüğü gibi M23 ve M31 maddeleri binişiklik göstermektedir. 31. madde için farklı faktörler arasındaki farkın 0.10'a oldukça yakın olduğu görülmektedir. Söz konusu maddelerin hangi bileşene ait olduğunu belirlemek için maddenin tekrar okunarak anlaşılır olup olmadığının, iki boyutlu ölçme yapıp yapmadığının incelenmesi gerekmektedir. "Dikkat edilecek olursa faktör analizi sadece bulunan sayıların yorumlanması değil, ölçeğe sık sık dönerek bir anlamda ölçeğin anlamsal yapısının da sorgulanması demektir” (Akyıldız, 2009). Bu durumda maddeler incelenerek doğrudan ilişkili bulunan tek bir faktör altında ele alınmıştır. Bu bağlamda, maddelerin hem içerik olarak hem istatistiksel olarak yüksek yük değeri verdiği faktörlerde yer almasının uygun olduğu sonucuna ulaşılmıştır. Yani, 23. 
maddenin altıncı faktörde, 31. Maddenin dördüncü faktörde yer almasının uygun olduğuna karar verilmiştir. Analiz sonucunda her faktörde önerilen madde sayısı üçtür. Üst limit yoktur. Ancak her faktörde kabul edilir en az iki madde olmalıdır (Çakır, 2014). Bu bağlamda, iki maddeden oluşan üçüncü, yedinci ve sekizinci faktörler tekrar incelenmiş, bu faktörlerin ele alınan yapı için önemli olması nedeniyle bu boyutların yer alması gerektiğine karar verilmiştir.

\section{Aşama: Faktörlerin İsimlendirilmesi}

Analizler sonucu belirlenen faktörler ortak özelliklerine göre; 1. Etkinlik düzenleme, 2. Türkçe öğretimi, 3. Planlama, 4. Dil öğretimi bilgisi, 5. İletişim kurma, 6. Dil-kültür ilişkisini bilme, 7. Materyal oluşturma, 8. Ölçme değerlendirme yapma, 9. Ortam hazırlama olarak adlandırılmıştır. Faktörler altında toplanan maddeler incelendiğinde ise bilişsel, duyuşsal ve davranışsal olarak ayrıştığ 1 anlaşılmıştır. Bu bağlamda bilgi, beceri, tutum ve değerleri kapsayan maddelerin yer aldığı 2 . ve 4 . faktörlerin bilişsel (bilmeyle ilgili); 5. ve 6. faktörlerin duyuşsal (duyguyla ilgili), 1, $3,7,8$ ve 9 . faktörlerin davranışsal (davranışla ilgili) boyutta ele alınarak 3 başlık altında toplanabileceği belirlenmiştir.

Millî Eğitim Bakanlığı'nca, 2004 yılında Temel Eğitime Destek Projesi kapsamında "öğretmenin sahip olması gereken bilgi, beceri, tutum ve değerleri" tanımlayan öğretmen yeterliklerini belirleme çalışmalarına başlandığı ve belirlenen yeterliklerin performansı vurguladığ 1 ve yeterlikler kapsamında oluşturulan performans göstergelerinin öğretmenlerin performanslarının değerlendirilmesinde de kullanılmasının amaçlandığı belirtilmektedir (MEB, 2010, s. 9). Böylece MEB tarafından Öğretmenlik Mesleği Genel Yeterlikleri ile Türkçe Öğretmeni Özel Alan Yeterlikleri ve Türk Dili ve Edebiyatı Özel Alan Yeterlikleri ve İngilizce Öğretmeni Özel Alan Yeterlikleri belirlenerek gereken performans tanımları yapılmıştır. Yeterliklerin yapısı, görevini yerine getirmek için öğretmenden sahip olması beklenilen; bilgi, beceri, tutum ve değerleri kapsayacak şekilde üç grupta oluşturulmuştur. Öğretmenin profesyonel davranışlar sergilemesi için, görevle ilgili bilgi, beceri ve tutumları eksiksiz kazanmış olması gerekmektedir (Aydın, 2011). Böylece, geliştirilen ölçek bilişsel, duyuşsal ve davranışsal boyutları kapsayacak nitelikte bir araç olarak kullanılabilecektir.

\section{Așama: Güvenirliğin İncelenmesi}

Çalışmada kullanılan ölçeğin güvenirlik düzeyinin belirlenmesi için genel yapı yani ölçeğin tümünde yer alan maddeler için güvenirlik analizi yapılmış ve ölçeğin güvenirlik katsayısı .723 olarak elde edilmiştir. Bu da ölçeğin güvenirliğinin yeterli düzeyde olduğunu göstermektedir. Ölçeğin alt faktörlerinin ayrı ayrı kullanılması uygun olmadığından, alt faktörler için ayrı güvenirlik katsayısı hesaplanmamıştır.

\section{Tartışma, Sonuç ve Öneriler}

Türkçenin yabancı dil olarak öğrenilmesinin köklü bir geçmişe sahip olduğu bilinmektedir. Günümüzde de yurt içinde/dışında pek çok resmi/özel kurum ve 
kuruluşta yabancı dil olarak Türkçe öğretimi yapılmaktadır. Ancak Türkçenin yabancı bir dil olarak öğretimi konusunda önemli sorunlar olduğu görülmektedir. En önemli konulardan birisi ise öğretmen niteliği sorunudur. Yabancı dil olarak Türkçe öğretimi alanında öğretmen yetiştirecek özel bir programın olmayışı, kurum ve kuruluşların farklı kaynaklardan yetişmiş öğretim elemanlarını kendi programları doğrultusunda konuyla ilgili eğitim verip sertifikalandırarak göreve almasına neden olmaktadır. Bu alanda genellikle Türkçe öğretmenleri, Türk dili ve edebiyatı öğretmenleri ve yabancı dil öğretmenleri görev yapmaktadır. Böylece öğretmenlerin niteliklerinde büyük farklılıklar bulunmaktadır.

Bu araştırmada amaçlanan, "Yabancı Dil Olarak Türkçe (YDOT) Öğretmeni Değerlendirme Ölçeği” geliştirmektir. $\mathrm{Bu}$ amaç doğrultusunda, alan taraması yapılarak yabancı dil olarak Türkçe öğretimi için gereken öğretmen niteliklerini ifade edecek maddeler hazırlanmıştır.

Maddelerin faktör analizi için uygun olup olmadığının belirlenmesi için yapılan KMO ve Bartlett Küresellik testi sonucunda KMO değeri 0,706; Bartlett küresellik testi sonucunda ise anlamlılık düzeyinin $p<0,05$ olduğu görülmüş ve bu durum, elde edilen verilerin faktör analizi için gerekli koşulları sağlandığını göstermektedir.

Ölçeğin faktör yapısının belirlenip geçerliğinin saptanması amacıyla faktör analizi yapılmış, toplam 46 maddeden faktör yük değerleri 0.45 üzeri olduğu belirlenen 30'u taslak ölçek maddeleri olarak analiz sürecine dâhil edilmiştir. Özdeğeri 12'den büyük olan faktör sayısı dokuz olduğu için, kalan 30 maddenin dokuz faktör altında ağırlıklandığı ve ölçeğin toplam varyans oranının \%62.94 olarak saptanması sonucunda yeterli bir değere sahip olduğu belirlenmiştir.

Daha sonra, veriler üzerinde açımlayıcı faktör analizi yapılarak ölçeğin yapı geçerliğini belirleyebilmek için yapılan analizler sonucunda maddelerin hangi faktör altında ağırlıklandığı belirlenmiş ve ortak özelliklerine göre; 1. Etkinlik düzenleme, 2. Türkçe öğretimi, 3. Planlama, 4. Dil öğretimi bilgisi, 5. İletişim kurma, 6. Dil-kültür ilişkisini bilme, 7. Materyal oluşturma, 8. Ölçme değerlendirme yapma, 9. Ortam hazırlama olarak adlandırılmıştır.

Faktörler altında toplanan maddeler incelendiğinde ise maddelerin bilişsel, duyuşsal ve davranışsal olarak ayrıştığı anlaşılmıştır. Bu bağlamda bilgi, beceri, tutum ve değerleri kapsayan maddelerin yer aldığı 2. ve 4. faktörlerin bilişsel (bilmeyle ilgili); 5. ve 6. faktörlerin duyuşsal (duyguyla ilgili), 1, 3, 7, 8 ve 9. faktörlerin davranışsal (davranışla ilgili) boyutta ele alınarak üç başlık altında toplanabileceği belirlenmiştir. Ölçeğin güvenirlik katsayısı 0.723 olarak elde edilmiştir. Bu bağlamda yabancı dil olarak Türkçe öğretiminde öğretmenin etkililik düzeyini belirlemede kullanılabilecek geçerli ve güvenilir bir ölçek geliştirildiği sonucuna ulaşılmıştır. Sonuçlar hazırlanan aracın ölçmeye uygun olduğunu gösterir niteliktedir. Böylece Türkçeyi yabancı bir dil olarak öğreten öğretmenlerin geliştirilmesi gereken eksik yönlerini belirlemelerini sağlayacak bir ölçek elde edilmiştir. Ayrıca bu ölçek 
Türkçenin yabancı bir dil olarak öğretilmesi konusunda öğretmen yetiştirilmesi için özel program oluşturulmasına da katkı sağlayacaktır. 


\section{Kaynakça}

Akyıldız, M. (2009). Faktör Analizi Tanıtımı ve Uygulanması, [Online]: http://www.istatistik.gen.tr/?p=75 adresinden 05.07.2018 tarihinde indirilmiştir.

Arslan, S. ve Özpınar, İ. (2008). Öğretmen Nitelikleri: İlköğretim Programlarının Beklentileri ve Eğitim Fakültelerinin Kazandırdıkları. Necatibey Ĕğitim Fakültesi Elektronik Fen ve Matematik Eğitimi Dergisi (EFMED), 2(1), 38-63.

Aydın, İ. (2011). Öğretmenlik Meslek Etiği, [Online]: http://inayetaydin.blogspot.com.tr/2011/09/ogretmenlik-meslek-etigi.html adresinden 09.12.2016 tarihinde indirilmiştir.

Barın, E. (2004). Yabancılara Türkçe Öğretiminde İlkeler. Türkiyat Araştırmaları, Hacettepe Üniversitesi Türkiyat Araştırmaları Enstitüsü, 1(1), 19-30.

Büyükkaragöz, S. ve Kesici, Ş. (1996). Öğretmenlerin Hoşgörü ve Demokratik Tutumları. Eğitim Yönetimi Dergisi, 2(3), 353-365.

Büyüköztürk, Ş. (2002). Faktör Analizi: Temel Kavramlar ve Ölçek Geliştirmede Kullanımı. Kuram ve Uygulamada Eğitim Yönetimi, 32, 470-483.

Büyüköztürk, Ş. (2007). Sosyal Bilimler için Veri Analizi El Kitabı, Ankara: PegemA Yayınc1lık.

Çakır, A. (2014). Faktör Analizi. Yayımlanmamış Doktora Tezi, İstanbul Ticaret Üniversitesi Sosyal Bilimler Enstitüsü, İstanbul.

Çelikten, M., Şanal, M. ve Yeni, Y. (2005). Öğretmenlik Mesleği ve Özellikleri. Erciyes Üniversitesi Sosyal Bilimler Enstitüsü Dergisi, 19/2, 207-237.

Durak, E. (2006). Yabancı Dil Olarak Türkçe Öğretimi Bağlamında Avrupa Ortak Dil Kriterleri Sorunsall. Yayımlanmamış Yüksek Lisans Tezi, İstanbul Üniversitesi, İstanbul.

Erdem, İ. (2009). Yabancılara Türkçe Öğretimiyle İlgili Bir Kaynakça Denemesi. Turkish Studies, 4(3), 888-937.

Gedik, D. (2009). Yabancılara Türkçe Öğretimi: Ankara Üniversitesi TÖMER ve Gazi Üniversitesi TÖMER Örneği. Yayımlanmamış Yüksek Lisans Tezi, Abant İzzet Baysal Üniversitesi Sosyal Bilimler Enstitüsü, Bolu.

Glatthorn, A. A., Jones, B. K., and Bullock, A. A. (2006). Developing highly qualified teachers. Thousand Oaks, Ca: Corwin Press.

Hengirmen, M. (1993). Türkçenin Yabancı Dil Olarak Öğretimi. Ankara Üniversitesi. TÖMER Dil Dergisi, 10, 5-9.

Hengirmen, M. (1997). Yabancı Dil Öğretim Yöntemleri ve TÖMER Yöntemi. Engin Yayınevi: Ankara. 
İş̧an, A. (2011). Türkçenin Yabancı Dil Olarak Önemi. Uluslararası Avrasya Sosyal Bilimler Dergisi, 2(4), 29-36.

Karagöz, Y. ve Kösterelioğlu, İ. (2008). İletiş̧im Becerileri Değerlendirme Ölçeğinin Faktör Analizi Metodu ile Geliştirilmesi. Dumlupınar Üniversitesi Sosyal Bilimler Dergisi, 21, 81-98.

Karakoç, Y.F. ve Dönmez, L. (2014). Ölçek Geliştirme Çalışmalarında Temel İlkeler. Tip Eğitimi Dünyası, 40, 39-49.

Kaya, Z. (1994). İkinci Dil Olarak Türkçe Öğretim Programlarının Değerlendirilmesi. Yayımlanmamış Yüksek Lisans Tezi, Ankara Üniversitesi Sosyal Bilimler Enstitüsü, Ankara.

Milli Eğitim Bakanlığı (MEB), Öğretmen Yetiştirme ve Eğitimi Genel Müdürlüğü. (2010). Okul Temelli Mesleki Gelişim Kılavuzu, Ankara.

MEB, Öğretmen Yetiştirme ve Eğitimi Genel Müdürlüğü. (2010). Türkçenin Yabancı Dil Olarak Öğretimi ve Bu Alan İçin Öğretmen Yetiştirmenin Önemi ve Gereği. Marmaris: Yabancı Dil Olarak Türkçe Öğretimi ve Öğretmenliği Çalıştayı Kitab1.

Mete, F. (2012). Yabanc1 Dil Olarak Türkçe Öğretimine İlişkin Öğretmen Görüşlerinin Değerlendirilmesi, Dede Korkut Türk Dili ve Edebiyatı Araştırmaları Dergisi, 1(1), 102-125.

Mete, F. (2013). Türkçeyi Yabancı Dil Olarak Öğreten Öğretmenlerin Özel Alan Yeterlikleri Üzerine Bir Araştırma. Yayımlanmamış Doktora Tezi, Gazi Üniversitesi, Eğitim Bilimleri Enstitüsü, Ankara.

Özer, M. A. (2009). Performans Yönetimi Uygulamalarında Performansın Ölçümü ve Değerlendirilmesi. Sayıştay Dergisi, 73, 3-29.

Seferoğlu, S. S. (2004). Öğretmen Yeterlilikleri ve Mesleki Gelişim. Bilim ve Aklın Aydınlığında Ĕ̈itim, 58, 40-45.

Şeker, H., Deniz, S. ve Görgen, İ. ( 2004). Öğretmen Yeterlikleri Ölçeği. Millî Eğitim Dergisi. 32(164), 105-118.

Tavşancıl, E. (2002). Tutumların Ölçülmesi ve SPSS ile Veri Analizi, Nobel Yayıncilık: Ankara.

Tosun, C. (2005). Türkçenin Yabancı Dil Olarak Öğretilmesi. Journal of Language and Linguistic Studies, 1(1), 22-28.

Türkoğlu, A. (1991). Öğretmen Yetiştirmede Amaçlar. Çukurova Üniversitesi Ĕgitim Fakültesi Dergisi, 1(5), 105-111.

Yıldız, C. (2012). Yurt Dışında Yaşayan Türk Çocuklarına Türkçe Öğretimi (Almanya Örneği). Ankara: Yurtdışı Türkler ve Akraba Topluluklar Başkanlığı. 
Yıldız, Ü. ve Tunçel, H. (2012). Yabancı Dil Olarak Türkçe Öğretimi. Yabancı Dil Olarak Türkçe Öğretiminde Karşılaşılan Sorunlar ve Öneriler (6. Bölüm), 173203. Ankara: Pegem.Net Akademi. 


\title{
Evaluation Scale for Teachers Turkish as a Foreign \\ Language
}

\begin{tabular}{cccc}
\hline ARTICLE TYPE & Received Date & Accepted Date & Online First Date \\
Research Article & 01.26 .2018 & 07.19 .2018 & 07.19 .2018 \\
\hline
\end{tabular}

Filiz Mete

Hacettepe University

\begin{abstract}
The aim of this research is to develop a "Turkish as a Foreign Language Teacher Assessment Scale" which could be used to determine effectiveness of teachers teaching Turkish as a foreign language. Thus, a document will be obtained that will enable teachers to identify the missing aspects that need improvement. For this purpose, firstly, the clauses to explain the teacher qualifications have been determined. Factor analysis was performed on the items obtained. Thus, a large number of items are collected as meaningful, small numbers of items and independent factors. 98 teachers who teach Turkish as a foreign language participated in the research. As a data collection tool, a questionnaire consisting of 46 items in 5 likert type was created and applied. To determine statistically validity and reliability of the structure item analysis factor analysis and cronbach's alfa reliability coefficient calculations were performed. As a result of the analyses, a 9-dimensional scale of 30 items was obtained. Dimensions were associated and collected in 3 (cognitive, emotional, behavioral) groups. The cronbach's alfa coefficient for determining the reliability level of the scale used in the study was 0.723 .
\end{abstract}

Keywords: Teaching Turkish as a foreign language, teacher assessment, factor analysis

\footnotetext{
${ }^{1}$ Corresponding Author: Assoc. Prof., Education Faculty, Turkish Education, filizmete@ hacettepe.edu.tr, https://orcid.org/0000-0002-8835-3884
} 


\section{Purpose and Significance}

The aim of this study is to develop a "Turkish as a Foreign Language Teacher Assessment Scale" which could be used to determine effectiveness of teachers teaching Turkish as a foreign language. Thus, a document will be obtained that will enable teachers to identify the missing aspects that need improvement.

\section{Method}

For this purpose, firstly, the clauses to explain the teacher qualifications have been determined. Factor analysis was performed on the items obtained. Thus, a large number of items are collected as meaningful, small numbers of items and independent factors. 98 teachers who teach Turkish as a foreign language participated in the research. As a data collection tool, a questionnaire consisting of 46 items in 5 likert type was created and applied. As a specialist, two academicians who work on teaching Turkish as a foreign language and a measurement evaluation expert have been identified and their views taken. The questionnaire was formed in the format of a 5point Likert sorting technique.

To determine statistically the validity and reliability of the structure item analysis (item analysis based on correlation and item analysis based on difference between upper and lower group averages), factor analysis and cronbach's alfa reliability coefficient calculations were performed.

\section{Results}

The results are named according to their common characteristics as follows: Activity planning, Turkish teaching, Planning, Knowledge of language teaching, Having language consciousness, Knowing language-culture relation, Creating material, Making assessment, Preparing environment, Communication. As a result of the analyzes, a 9-dimensional scale of 30 items was obtained. Dimensions were associated and collected in three (cognitive, emotional, behavioral) groups. The cronbach's alfa coefficient for determining the reliability level of the scale used in the study was .723. 